\title{
Impact of silver nanoparticles and two biological treatments to control soft rot disease in sugar beet (Beta vulgaris $\mathrm{L}$ )
}

\author{
Nasr A. Ghazy ${ }^{1 *}$, Omnia A. Abd El-Hafez ${ }^{2}$, A. M. El-Bakery ${ }^{1}$ and Dalia I. H. El-Geddawy ${ }^{3}$
}

\begin{abstract}
Background: Soft rot disease caused by Pectobacterium carotovorum was observed in various crops which lead to yield shortages and economic losses.

Main body: Therefore, both in vitro and in vivo experiments, aim to assess the effect of nanoparticles and biological treatments to control soft rot disease in sugar beet plant. The treatments comprised three silver nanoparticles (Ag NPs) concentrations (50,75, and 100 ppm), three Spirulina platensis extract concentrations (50, 75, and 100\%), and Bacillus subtilis $\left(1 \times 10^{9} \mathrm{CFU} \mathrm{ml}\right) 100 \%$. Under in vitro condation, results of the antibacterial activity showed that the zones of inhibition recorded $4.33 \mathrm{~cm}$ for $100 \mathrm{ppm}$ Ag NPs, $0.43 \mathrm{~cm}$ for $100 \%$ algal extract, and 0.2 $\mathrm{cm}$ for bacterial treatments. Also, disease incidence \% of bacterial soft rot was significantly decreased in all treatments in pot and field experiments. For resistant enzymes activity, B. subtilis 100\% showed the most effect (84 $\left.\mathrm{mg} \mathrm{min}{ }^{-1}\right)$, followed by S. platensis extract 75\%, $\left(57 \mathrm{mg} \mathrm{min}^{-1}\right)$, and Ag NPs $75 \mathrm{ppm}\left(44 \mathrm{mg} \mathrm{min}^{-1}\right)$, for poly phenol oxidase (PPO) at 81 days after sowing (DAS), but at 102 DAS revealed opposite results. On the contrary, peroxidase (PO) at 81 DAS showed different effects where treatment with S. platensis extract $100 \%$ increased it significantly $\left(0.546 \mathrm{mg} \mathrm{min}^{-1}\right)$ compared to control $\left(0.535 \mathrm{mg} \mathrm{min}^{-1}\right)$. The same trend was observed at $102 \mathrm{DAS}$. These results were reflected on sugar quality where Ag NPs 100 ppm treatment recorded the highest significant value (20.5\%) followed by S. platensis 75\% (19\%); however, the differences among them were not statistically significant.
\end{abstract}

Conclusion: This study indicated that the potential benefits of using silver nanoparticles and two biological treatments to control soft rot disease in sugar beet (Beta vulgaris $\mathrm{L}$ ).

Keywords: Soft rot, Sugar beet, Pectobacterium carotovorum, Enzymes, Nanosilver particles, Spirulina platensis, Bacillus subtilis

\section{Background}

Sugar beet (Beta vulgaris L.) is one of the world's two major sugar crops (Bastas and Kaya 2019). It is an herbaceous dicotyledonous plant belonging to the family Chenopodiaceae. In the north of Egypt, soft rot disease was observed which causes serious losses in sugar beet yield. The causal bacterial of vascular necrosis and rot diseases in storage roots of sugar beet was discovered in 1972 by

\footnotetext{
* Correspondence: nasrghazy@yahoo.com

'Maize and Sugar Crops Diseases Department, Plant Pathology Research Institute, Agricultural Research Center, Giza 12112, Egypt

Full list of author information is available at the end of the article
}

Thomson and Schroth 1972. The crop is attacked by different strains of bacteria causing soft rot as Erwinia carotovora subsp. carotovora (Ecc), E. carotovora subsp. betavasculorum (Ecb), and recently Burkholderia cepacia (Abdalla et al. 2019), though Pectobacterium carotovorum subsp. betavasculorum is the main causal agent of sugar beet soft rot (Metzger 2018). Presently, P. betavasculorum (Thomson) Gardan (syns. P. carotovorum subsp. betavasculorum (Thomson) Hauben and E. carotovora subsp. betavasculorum Thomson were the causal pathogens of soft rot disease in sugar beet (Bull et al. 2010; Harveson et al. 2009).

\section{Springer Open}

(- The Author(s). 2021 Open Access This article is licensed under a Creative Commons Attribution 4.0 International License, which permits use, sharing, adaptation, distribution and reproduction in any medium or format, as long as you give appropriate credit to the original author(s) and the source, provide a link to the Creative Commons licence, and indicate if changes were made. The images or other third party material in this article are included in the article's Creative Commons licence, unless indicated otherwise in a credit line to the material. If material is not included in the article's Creative Commons licence and your intended use is not permitted by statutory regulation or exceeds the permitted use, you will need to obtain permission directly from the copyright holder. To view a copy of this licence, visit http://creativecommons.org/licenses/by/4.0/. 
Species of $P$. carotovora are generally the cause of soft rot symptoms in some horticultural crops causing physical, physiology, and chemistry changes that causes severe damage in quality and sugar yield (Schaad 2001).

Over use of fertilizers and accumulation of pesticides are the most important problems of modern agriculture. This possesses a serious threat to food security of human on this planet. In order to control that, nanoagrochemicals were required in modern agriculture (Sekhon 2014; Campos et al. 2015; Pulimi and Subramanian 2016). The use of nanomaterials in agro-production has several dimensions including the sustainable agroproduction, the agro-environmental sustainability, the enhancement of agro-productivity, and the management of agro-wastes. Without these previous dimensions, it is very difficult to reach to the global security in all directions including food, soil, water, and environment securities. The role of nanoparticle was reported by several investigators around their characterizations, effects, formulations, and their applications in management of plant diseases (Al-Samarrai 2012; Álvarez et al. 2016; Dubey and Mailapalli 2016; Pandey et al. 2016). Silver nanoparticles as a pesticide have a great attention for agricultural use (Bhattacharyya et al. 2016). Nanoparticles were considered carefully in several agroenvironmental studies including the interactions among nanoparticles under soil-plant systems (Wu et al. 2016; Tripathi et al. 2017; Zhang et al. 2017). The impact of nanoparticles application on microbial community in soils was studied (Simonin and Richaume 2015; Read et al. 2016; Samarajeewa et al. 2017). The applied nanoparticles to cultivated crops may cause various physiological and biochemical changes depending on the properties of these nanoparticles, their concentration, and they vary from plant to plant as well as different soil properties (Tripathi et al. 2017). Some studies suggested that metallic silver nanoparticles (AgNPs) increased the root length in maize and cabbage plants in comparison with $\mathrm{AgNO}_{3}$ (Pokhrel and Dubey 2013). Nanoparticles (NPs) can be used to directly suppress pathogen infection, leading to an increase in crop growth and yield; NPs also were required as plant micronutrients, raising the potential for additional improved growth through nutritional benefits. Particles such as $\mathrm{Ag}, \mathrm{ZnO}, \mathrm{Mg}, \mathrm{Si}$, and $\mathrm{TiO} 2$ likely suppress crop diseases directly, through antimicrobial activity (Ram Prasad and Suranjit 2014). Recently, algae are one of the chief biological agents that have been studied for the control of plant pathogenic fungi, particularly soil-borne diseases (Hewedy et al. 2000). Cyanobacteria and eukaryote algae occur in freshwater, marine, and terrestrial habitats, and they produce biologically active compounds that have antifungal activity against plant pathogens. Actually, these microorganisms comprise most of the world's biomass. Blue-green algal compounds have the efficiency against the development of each pathogenic or antagonistic microorganisms as well as their effect on the antagonistic ability of bioagents under in vitro conditions (El-Mougy and AbdelKader 2013). Several Bacillus species have proved to be effective against a broad range of plant pathogens. They have been reported as plant growth promoter, systemic induced resistance, and used for production of a broad range of antimicrobial compounds (lipopeptides, antibiotics, and enzymes) and competitors for growth factors (space and nutrients) with other pathogenic microorganisms through colonization (Shafi et al. 2017). The earlier research reported that different plant pathogenic diseases can be suppressed by natural antagonistic microorganisms (Cook et al. 2002). The effect of Bacillus subtilis as antimicrobial agents for the plant pathogen, Erwinia carotovora, was studied as highly agent against many fungal pathogens. Bacillus species have become attractive biological control agents due to their ability to produce hard, resistant endospores and antibiotics which control a broad range of plant pathogens (Cavaglieri et al. 2005; Deng et al. 2011). Biological control agent $B$. subtilis $\left(10^{9} \mathrm{cfu} / \mathrm{ml}\right)$ has potential in inhibiting the growth of pathogenic E. carotovora by showing the clear zones (Istiqomah and Toyibah 2013). The objective of the present study was to the possible use of silver nanoparticles, Spirulina platensis and B. subtilis, to evaluate their efficacy against sugar beet soft rot caused by $P$. carotovora, as a possible new trend for disease control.

\section{Material and methods \\ Plant materials}

The present study was carried out under field conditions of Maize and Sugar Crops Disease Department, at Sakha Agricultural Research Station, Kafrelsheikh, Egypt, during two growing seasons 2017/2018 and 2018/2019. Greenhouse and laboratory experiments were carried out in Maize and Sugar Crops Disease Department. Sugar beet (Beta vulgaris L., Chenopodiaceae) cultivar Oscar-poly, as a susceptible cultivar to root soft rot disease was the target of the evaluation by silver nanoparticles (Ag NpS), Algal culture extracts and B. subtilis were used against bacterial root soft rot disease on sugar beet. The cultivar used in this study was obtained from the Sugar Crops Research Institute, Agricultural Research Center, Giza, Egypt.

\section{Used chemical and microbial materials}

Silver nanoparticles (50, 75, and $100 \mathrm{ppm}$ ); algal culture extracts (100\%, $75 \%$, and $50 \%)$, and B. subtilis $100 \%$ were tested against $P$. carotovorum. Check plants were treated with sterilized water only and kept as a control. 


\section{Isolation of the casual bacterium}

Causal bacterium was isolated from diseased sugar beet roots with visible symptoms of soft rot. Infected root samples were surfaces disinfected with $5 \%$ sodium hypochlorite, then washed at three successive times in sterilized water. A small piece of tissue removed from margins of the necrotic vascular bundles was macerated and suspended in $5 \mathrm{ml}$ sterile water, allowed to settle for 5 min before serial dilution. A loop of resulting suspension (from dilution $10^{3}$ ) was streaked on the solidified dry plates of nutrient agar (NA) medium. The plates were incubated at $28{ }^{\circ} \mathrm{C}$ for $24 \mathrm{~h}$ (Difco manual 1953).

\section{Identification of the bacterial isolates}

Identification of the isolated bacterium as Erwinia was performed according to their morphological and cultural characteristics by the procedures as described by Garrity et al. (2004). A series of physiological and biochemical tests were performed following standard methods for characterization of selected soft rot bacteria, i.e., anaerobic growth, yellow colonies on YDC and NA media, fluorescent pigments on $\mathrm{KB}$ medium, growth at $37{ }^{\circ} \mathrm{C}$, reducing substances from sucrose, sensitivity to erythromycin, indole production, acid production from (lactose, inulin, cellobiose, glycerol, and starch) oxidase test, urease activity, and utilization of sucrose, maltose, Dtartrate, and arginine. The common genera were subjected to further tests to identify their species according to Schaad (2001); Sotokawa and Takikawa (2004). Pure colonies were maintained in $70 \%$ glycerol solution and stored at $-20{ }^{\circ} \mathrm{C}$.

\section{Biosynthesis of silver nanoparticles}

According to the methods used by Rabie et al. (2013), isolation and identification of Fusarium oxysporum, biomass preparation, biosynthesis of AgNPs, and characterization of AgNPs were performed as follows.

\section{Isolation and identification of Fusarium oxysporum as fungal culture}

One isolate of $F$. oxysporum isolated from wilted tomato plants was made on potato dextrose agar (PDA) The morphological characteristics were determined by microscopic methods. Isolates were selected, purified, maintained on PDA slant, and stored at $4{ }^{\circ} \mathrm{C}$ until further use.

\section{Biomass preparation}

To prepare fungal biomass for biosynthesis of AgNPs, two fungal discs, $4 \mathrm{~mm}$ each, cut from $F$. oxysporum culture were inoculated into Malt extract, Glucose, Yeast extract, and Peptone broth medium (MGYP) and incubated at $28{ }^{\circ} \mathrm{C}$ on a rotary shaker $(120 \mathrm{rpm})$ for $96 \mathrm{~h}$. The growth was harvested by filtration through filter paper (Whatman no. 1) and then washed with sterile distilled water to remove any remains of the medium. A 25-g fungal biomass (wet weight) was placed in individual flasks containing $100 \mathrm{ml}$ sterile distilled water. The flasks were incubated under the conditions described above for $24 \mathrm{~h}$. Finally, the biomass was filtered and the crude culture filtrate was obtained.

\section{Biosynthesis of AgNPs}

AgNPs were synthesized using $50 \mathrm{ml}$ cell filtrate mixed with $10 \mathrm{ml} \mathrm{AgNO} 3$ solution $(\mathrm{mmol} / \mathrm{l})$ in a $250-\mathrm{ml}$ Erlenmeyer flask, incubated at $28{ }^{\circ} \mathrm{C}$ on a rotary shaker $(120$ $\mathrm{rpm}$ ) in darkness for $24 \mathrm{~h}$. A flask devoided silver ions was used as control. After incubation, AgNPs were concentrated by centrifugation of the reaction mixture at $10,000 \mathrm{rpm}$ for $10 \mathrm{~min}$ twice and then collected.

\section{Characterization of AgNPs \\ UV-vis absorbance spectroscopic analysis}

The bioreduction of silver nitrate (AgNO3) to AgNPs was monitored periodically by UV-vis spectroscopy (JascoV630made in Europe) after the dilution of the samples with deionized water. A UV-vis spectrograph of the silver and nanoparticles was recorded by using a quartz cuvette with water as reference. The UV-vis spectrometric readings were recorded at a scanning speed of 200 $800 \mathrm{~nm}$.

\section{Transmittance electron microscope (TEM) analysis of AgNPs}

The suspension containing AgNPs was sampled for TEM analysis using JEOL model 1230 operated at 100 $\mathrm{kV}$ connected with CD camera, Japan electron microscope. TEM samples were prepared by placing a drop of the suspension of AgNPs solutions on carbon-coated copper grids and allowed to dry for $4 \mathrm{~min}$. The shape and size of AgNPs were determined from TEM micrographs (Rabie et al. 2013).

\section{Preparation of algal culture}

Inoculated $2 \mathrm{ml}$ of $S$. platensis was obtained from Soil, Water and Environmental Research Institute, Agricultural Research Center (A.R.C), Egypt, which is previously maintained in Zarrouk's liquid medium in conical flask of $250 \mathrm{ml}$ having $50 \mathrm{ml}$ of Zarrouk media (Zarrouk 1966). Growth of the culture was done in an illuminated (5Klux) growth room at $30 \pm 2{ }^{\circ} \mathrm{C}$ under $12 / 12 \mathrm{~h}$ light/ dark cycles. Manual shaking of cultures was done 3-4 times daily (Pandey et al. 2010). After 20 days, the biomass from the cultural medium was separated by centrifugation $\left(40 \mathrm{~min}, 800 \mathrm{~g}, 10^{\circ} \mathrm{C}\right.$ ), filtration of culture media by filter paper Whatman No.1, and then using the filtrate output as treatment after sterilization. The extracted compounds were detected by gas 
chromatography mass-spectrum (GC-MS) for making qualitative and quantitative analysis

\section{Preparation of antagonistic bacterium}

Antagonistic bacterium obtained from the Culture Collection Unit of Plant Pathology Department, National Research Centre, Egypt, was used in the present work.

B. subtilis was cultured in nutrient broth medium (peptone $5.0 \mathrm{~g} / \mathrm{l}$; beef extract $3.0 \mathrm{~g} / \mathrm{l} ; \mathrm{NaCl} 5.0 \mathrm{~g} / \mathrm{l}$; distilled water $1000 \mathrm{ml}$; pH 6.8-7.2) until having a concentration of $10^{9} \mathrm{cfu} / \mathrm{ml}$ (Anonymous 1957).

\section{Sterilization of treatments of antagonistic bacterial and algal culture}

All biological treatments were sterilized by exposure to the vapor of chloroform by putting every 3 small bottles (20 ml sized) on conical flask $(250 \mathrm{ml})$ having $25 \mathrm{ml}$ of chloroform, then closed with parafilm for 5 days to kill all cells of any microorganisms according to the technique supplied by Vidaver-Anne et al. (1972) and adapted by EL-Bakery (2010) as shown in Fig. 1.

\section{Agar well-diffusion assay}

Antibacterial potency of synthesized AgNPs (50, 75, and $100 \mathrm{ppm})$, algae culture extracts (100\%, 75\%, and 50\%), and B. subtilis (100\%) for inhibiting growth of $P$. carotovorum subsp. betavasculorum and syn. E. carotovora was tested in vitro on (beef extract $3 \mathrm{gll}$, peptone $5 \mathrm{gll}$, yeast $5 \mathrm{~g} \backslash \mathrm{l}$, glucose $5 \mathrm{~g} \backslash \mathrm{l}$, agar $15 \mathrm{~g} \backslash \mathrm{l}, \mathrm{pH}$ 7.2) medium using the agar well-diffusion assay according to Bakht et al. (2011). Three replicates were incubated at $28+2{ }^{\circ} \mathrm{C}$ for 3 days followed by the determination of the clear zones width.

\section{Greenhouse experiment}

The seeds of sugar beet cultivar Oscar-poly were sown in pots $(35 \mathrm{~cm}$ in diameter) containing sterilized soil.

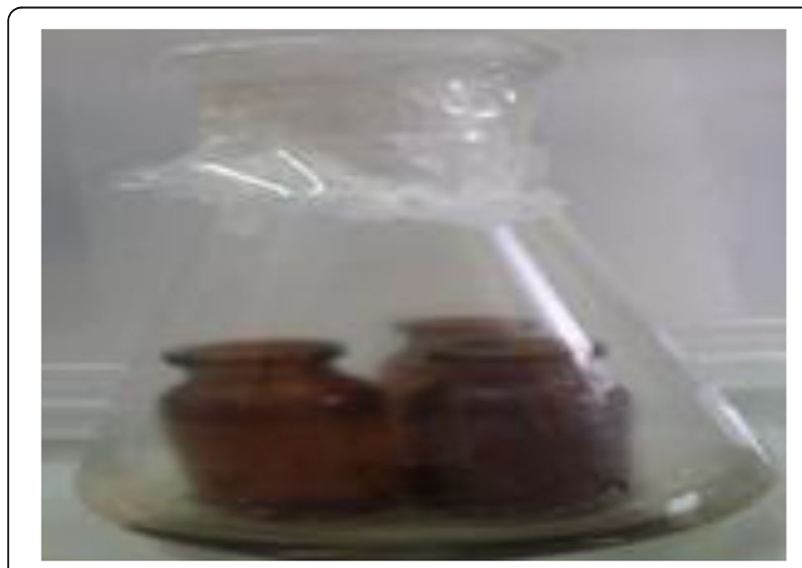

Fig. 1 Sterilization of bacteria and algae supernatant by vapor of chloroform
Three individual seeds were sown in each pot pattern, 2$\mathrm{cm}$ deep, watered, and transferred to a greenhouse at 29 ${ }^{\circ} \mathrm{C}$ and a 12-h light/dark cycle for optimum plant growth. All agriculture practices (irrigation, thinning, and fertilization) were done as recommended. Twomonth-old sugar beet seedlings were inoculated by inserting a small amount of bacterial cell $(109 \mathrm{cfu} / \mathrm{ml})$ into the petioles using a sterile toothpick (Thomson and Schroth 1977). Then, plants were placed in clear polyethylene bag in a growth room for $48 \mathrm{~h}$ at $28{ }^{\circ} \mathrm{C}$, then un-bagged. Control plants were treated with sterilized distilled water. Ten plants were inoculated with pathogenic isolate. Silver nanoparticles (100, 75, and $50 \mathrm{ppm}$ ), algal culture extracts $(100 \%, 75 \%$, and $50 \%)$, and B. subtilis $(100 \%)$ were sprayed two times with 2 weeks interval after 1 week after inoculation with pathogenic bacteria. After 30 days of the last spray, according to the methods of Metzger (2018), plants were examined visually and rated for the presence of foliar, crown, and root symptoms of bacterial soft rot and percentages of disease incidence were calculated.

\section{Field experiments}

This study was carried out at the research experiment farm at Sakha Agriculture Research Station during 2017/ 2018 and 2018/2019 growing seasons using sugar beet cultivar Oscar-poly imported from Maribo SeedDenmark. Eight treatments in including untreated plots (control) were prepared. The treatments were three concentrations of AgNPs (50, 75, and $100 \mathrm{ppm}$ ), algal culture extracts (50, 75, and 100\%), and B. subtilis $100 \%$. All treatments were sprayed twice; the first one was after 60 days from sowing when the first sign of disease was appeared, followed by the second one after 21 days ( 81 days from sowing). Samples for the chemical studies were taken at the end of the first application and the second one at harvest. Concerning the disease incidence, records were made at harvest stage. Nitrogen fertilizer was added as urea $(46.5 \% \mathrm{~N})$ in two equal rates, one after thinning and 1 month later were applied at the level of $15 \mathrm{~kg} \mathrm{~N} /$ fed. Phosphorus fertilizer in form of calcium superphosphate $\left(15.5 \% \mathrm{P}_{2} \mathrm{O}_{5}\right)$ was applied at the level of $31 \mathrm{~kg} \mathrm{P}_{2} \mathrm{O}_{5} / \mathrm{fed}$ during soil preparation, whereas potassium fertilizer in form of potassium sulfate $(48 \%$ $\mathrm{K}_{2} \mathrm{O}$ ) was added at the level of $48 \mathrm{~kg} \mathrm{~K}_{2} \mathrm{O} /$ fed, once with the 1st nitrogen application.

\section{Chemical studies Enzymes activity}

The activities of peroxidase ( $\mathrm{PO}$ ) and poly phenol oxidase (PPO) enzymes were determined. PO activity was measured using guaiacol/ $\mathrm{H}_{2} \mathrm{O}_{2}$ as substrate according to Lobarzewski (1990) by spectrophotometer. PPO activity 
was determined using catechol as substrate according to Mariey et al. (2016) by spectrophotometer.

\section{Chemical components of roots}

Juice analysis was made in El-Fayuom Sugar Factory Laboratory. Corrected sugar content (white sugar) was calculated by linking the beet non-sugar $\mathrm{K}, \mathrm{Na}$, and $\alpha$ amino $\mathrm{N}$ (expressed as a mill equivalent/100 $\mathrm{g}$ of beet) according to Harvey and Dutton (1993). The method is currently used by the factory.

$$
\begin{gathered}
\text { Juice purity } \%(\mathrm{Qz})=\mathrm{ZB} / \mathrm{Pol} \times 100 \\
\mathrm{ZB}=\operatorname{pol}-[0.343(\mathrm{~K}+\mathrm{Na})+0.094 \mathrm{AmN}+0.29]
\end{gathered}
$$

Where $\mathrm{ZB}=$ corrected sugar content (\% per beet) or extractable white sugar

$\mathrm{Pol}=$ gross sugar $\% \mathrm{AmN}=\alpha$-amino- $\mathrm{N}$ determined by the "blue number method."

\section{Juice impurities}

Potassium, sodium, and $\alpha$-amino nitrogen in meq/100 g of beet) in roots were determined by means of an Automatic Sugar Polarimetric.

\section{Statistical analysis}

The data were subjected to one-way analysis of variance (ANOVA) as illustrated by Gomez and Gomez (1984). Duncan multiple test was applied to compare among treatment means at 0.05 probability level.

\section{Results and discussion}

\section{Biosynthesis of silver nanoparticles}

F. oxysporum was isolated from tomato plants with typical wilt symptoms. This fungus was identified based on the morphological and microscopic characteristics. This culture was preserved in PDA (potato dextrose agar) medium and transferred to MGYP (maltose-glucoseyeast-peptone) medium for the synthesis of silver nanoparticles. Aqueous silver nitrate ions were reduced during exposure to the $F$. oxysporum cell filtrate. The color of the reaction mixture changed from pale yellow to yellowish brown as shown in Fig. 2a, which indicated the formation of silver nanoparticles. A color appeared upon addition of $\mathrm{AgNO}_{3}$ solution to the cell-free extract of $F$. oxysporum is due to the surface plasma resonance of the synthesized AgNPs as pointed previously by Abdel-Aziz et al. (2014).

\section{Characterization of AgNPs UV-vis absorbance spectroscopic analysis}

Spectrophotometric study revealed that the maximum UV-vis absorbance of the biosynthesized AgNPs was $430 \mathrm{~nm}$ (Fig. 2b). Previous reports indicated that the UV-vis absorbance of AgNPs may be different with the microorganisms used, and the recorded values were in the range of 410-460 $\mathrm{nm}$ (Darroudi et al. 2011).

\section{Transmission electron microscopic (TEM) analysis of AgNPs}

TEM analysis revealed the production of spherical and oval AgNPs with a particle about 16 to $27 \mathrm{~nm}$ (Fig. 2c). AgNPs do not adhere to each other indicating their stability by protein capping. Transmission electron microscopy (TEM) is considered a high-resolution tool that gives actual information concerning particle size and shape (Sathishkumar et al. 2009). Recent TEM has the ability to image atoms directly in specimens at resolutions about $1 \mathrm{~A}^{\circ}$, smaller than inter-atomic space. This technique is very necessary for characterizing materials at a length scale from atoms to hundred nanometers. All AgNPs have a spherical and oval form and diameters about 16 to $27 \mathrm{~nm}$. The present data are in agreement with spherical and oval forms of prepared AgNPs highly

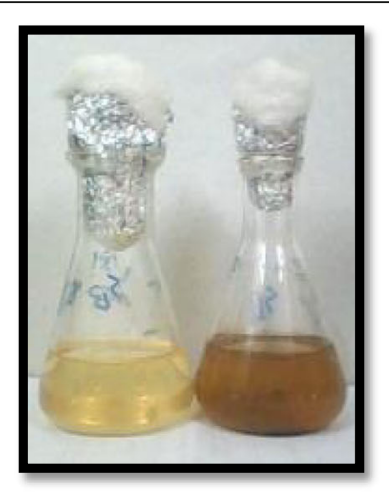

$\mathbf{a}$

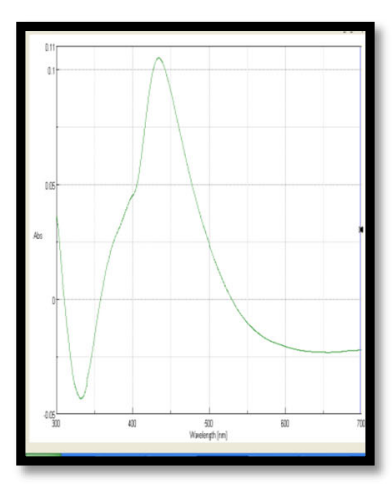

b

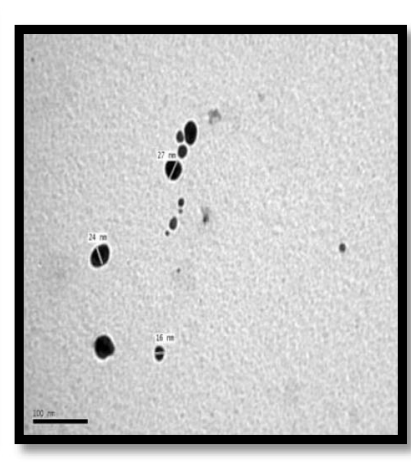

c

Fig.2 a Conical flasks containing cell-free extract in aqueous solution of $10^{-3} \mathrm{M}$ of AgNo3 for F. oxysporum and the beginning of the reaction (left flask) and after $72 \mathrm{~h}$ of reaction (right flask). Formation of AgNPs is detected by color change observation of reaction medium from colorless to yellowness or dark brown. b UV-vis absorbance spectroscopic analysis of the AgNps. c Transmission electron microscopic analysis of the AgNPs 
agreed with the fact given by Rabie et al. (2013). This confirms that surface plasmon peak around $420 \mathrm{~nm}$ indicate that the AgNPs have spherical form.

\section{Determination compound(s) biosynthesis by Spirulina} platensis on gas chromatography-mass spectrum (GC-MS) A total of 19 compounds were identified in algal extract. The results in Table 1 and Fig. 3 revealed that the major compounds which extracted from $S$. platensis were (crown-4-ether, malonic acid, and cis-vaccenic acid). Their peaks appeared at $6.722,3.69$, and 16.86 min of retention time, respectively. For absolute quantification, the amounts of endogenous compounds can be calculated from their peak areas and the labeled internal standard. Crown-4-ether had maximum peak area; thus, the highest concentration among the compounds extracted from $S$. platensis was $18.85 \%$ and malonic acid was ranked in the second order. This had $18.53 \%$ of peak area. In the 3rd order, cis-vaccenic acid showed $14.54 \%$ peak area.

\section{Causal bacteria}

Causal bacterium was isolated from diseased sugar beet roots with soft rot disease and was identified as $P$. carotovorum.

\section{Laboratory experiments}

In this experiment, the basal medium was nutrient agar medium, making seeded medium in order to grow Pectobacterium. F. oxysporum fungus has been explored as potential bio factor for synthesis of metallic nanoparticles through the reduction of silver fraction. Zarrouk medium was used for growing S. platensis, and nutrient medium was used for $B$. subtilis.

The results in Table 2 and Fig. 4 revealed that the Ag Nps had maximum effect compared to other treatments. While Spirulina and Bacillus had looting influence on growth rate of the pathogen, they decreased the growth of Pectobacterium as shown in Figs. 5 and 6. Meanwhile, not all Ag Nps concentrations had the same effect on growth rate of experimental microorganisms. The 50 ppm of silver nanoparticles showed the lowest growth rate $(0.33 \mathrm{~cm}$ clear zone), and higher concentrations of $\mathrm{Ag} \mathrm{Nps}$ at 100 and $75 \mathrm{ppm}$ showed pronounced effect on its growth rate that decreased the growth of Pectobacterium to 4.33 and $2.66 \mathrm{~cm}$ as clear zones,

Table 1 Compound(s) biosynthesis by Spirulina platensis on gas chromatography-mass spectrum (GC-MS)

\begin{tabular}{llll}
\hline Compound name & Compound class & RT min & Area sum \% \\
\hline Crown-4-ether & Volatile compounds & 6.722 & 18.85 \\
Malonic acid & Organic acid & 3.69 & 18.53 \\
Cis-vaccenic acid & (omega 7 fatty acid) & 16.86 & 14.54 \\
\hline
\end{tabular}

respectively. The findings coincided with disease incidence and efficiency percentage mentioned in Table 2.

The results of this investigation revealed that AgNps inhibited the growth of experimental pathogen and the inhibition of growth was different according to concentration of treatment. These results were in consistent with Zhang et al. (2017) who reported the activity of colloid nanosilver against wide range of microorganisms. The mechanism behind the antimicrobial activity of nanosilver particles is basically due to interaction with sulfur containing proteins in bacterial cell wall as well as with phosphorus containing compounds like DNA and finally cell lyses and death occurred.

The results in the present investigation were in accordance with those on NPs that can be used to directly suppress pathogen infection, leading to an increase in crop growth and yield. NPs also were required as plant micronutrients, raising the potential for additional growth through nutritional benefits. Particles such as $\mathrm{Ag}, \mathrm{ZnO}$, $\mathrm{Mg}, \mathrm{Si}$, and $\mathrm{TiO}_{2}$ likely suppressed crop diseases directly, through antimicrobial activity (Ram Prasad and Suranjit 2014). Esteban-Tejeda et al. (2009), Park et al. (2006), and Jo et al. (2009) reported that fungi and gram-positive and gram-negative bacteria were affected by nanoparticles. Also, Escherichia coli and Staphylococcus aureus were affected as reported by Priebe et al. (2017).

\section{Pots and field experiments}

Data in Table 3 showed the relative efficacy and disease severity of tested plants against bacterial root soft rot in sugar beet in pots and field conditions. Disease incidence $\%$ of bacterial root soft rot was significantly decreased at all tested treatments relative to control two experiments. The Ag Nps 100 ppm and Spirulina 100\% were the most effective ones against bacterial root soft rot in both pots and field experiments followed by $75 \mathrm{ppm}$ and $50 \mathrm{ppm}$ as well as Spirulina. Seventy-five percent and $50 \%$ and $B$. subtilis $100 \%$ treatment showed the least efficacy. The disease incidence of nano $100 \mathrm{ppm}$ that gave the best results in pots experiment was $7.59 \%$ and its efficiency was $91.72 \%$. This result agreed with those of the field experiments of first and second seasons where the value of disease incidence \% were $1.67 \%$ and 2.27 and the efficiency \% were 94.11 and 92.56 , respectively, and disease incidence with B. subtilis was 83.34 and its efficiency\% was 9.10 in pot experiments, but in field experiments in both seasons, the results were relatively high comparing to pot experiments, as the value of disease incidence $\%$ were 10.00 and 10.60 and for efficiency \% were 64.71 and 65.25 for first and second field experiments, respectively.

Silver NPs play a potent inhibitory role to manage microorganisms and phyto-pathogens management. Although the mechanism of NP Ag toxicity is not fully characterized, the antimicrobial activity seemed to be 


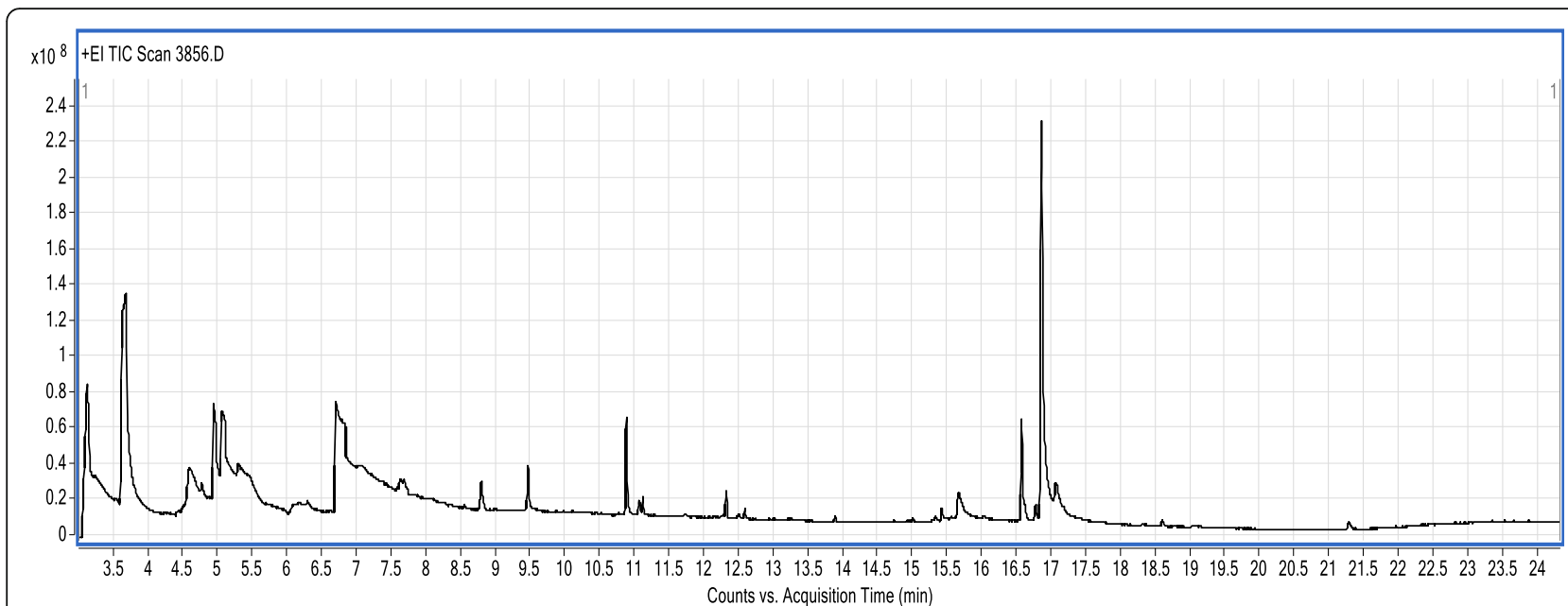

Fig. 3 Compounds concentration peak areas which were extracted from Spirulina platensis

driven by releasing $\mathrm{Ag}^{+}$ions, with some additional effects mediated through the elemental NPs themselves. For example, it is known that $\mathrm{Ag}^{+}$ions bind to cysteinecontaining proteins on plasma membranes, causing both physiological and biochemical damage that compromise membrane integrity. Subsequent penetration of Ag into the cytoplasm causes the inactivation of critical enzyme systems and cell death (Ocsoy et al. 2013). The effect of AgNPs was showed on pathogenic fungi caused disease in ryegrass (Lolium perenne) and caused a 50\% reduction in colony formation (Jo et al. 2009).

Silver NPs inhibited the activity of Colletotrichum spp. (anthracnose pathogen) in field trials (Lamsal et al. 2011). Both the mentioned later papers indicated that the Ag NPs have damaged and penetrated the cell membrane, subsequently reduce and decreased infection. Jo et al. (2009) and Lamsal et al. (2011) also have reported, on the prophylactic application of Ag NPs (4-8 nm), enhanced disease suppression, suggesting an alternative mechanism for induction of resistance mechanisms.

Table 2 Effect of Ag Nps ppm, Spirulina \%, and Bacillus sp. on the growth rate culture of Pectobacterium carotovora

\begin{tabular}{ll}
\hline Treatments & Growth rate \\
\hline Ag Nps 50 ppm & $0.33 \mathrm{~cd}$ \\
Ag Nps 75 ppm & $2.66 \mathrm{~b}$ \\
Ag Nps 100 ppm & $4.33 \mathrm{a}$ \\
Sp $\mathbf{5 0} \%$ & $0.13 \mathrm{f}$ \\
Sp 75\% & $0.27 \mathrm{de}$ \\
Sp $\mathbf{1 0 0} \%$ & $0.43 \mathrm{C}$ \\
Bs $\mathbf{1 0 0 \%}$ & $0.2 \mathrm{ef}$ \\
Control (distilled water) & $0 \mathrm{~g}$ \\
\hline
\end{tabular}

Sp Spirulina platensis, Bs Bacillus subtilis

In a column means followed by a common letter are not significantly different at $1 \%$ level by DMRT
A number of cyanobacteria and eukaryote algae is particularly macro-algae, known to produce an array of biologically active compounds and can be grown in quantitatively in mass culture. They are suitable candidates for exploitation as bio-control agents of plant pathogenic bacteria and fungi (Papavizas and Lumsden 1980; Abdel-Kader 1997 and Kulik 1995).

Although the cyanobacteria are mostly photoautotrophic, some are facultative heterotrophs, capable of growing on certain substrates in darkness. Also, some are nonphototrophic and hence, are obligate heterotrophs. Much additional work remains to be done, however, to evaluate thoroughly the role cyanobacteria and algae and their products in environment (Kulik 1995). Moreover, Cyanobacteria were considered chief biological agents that have been studied for the control of plant pathogens, particularly soil borne fungi (Abdel-Kader 1997). This is mainly due to production of various biologically active compounds; those could operate in biological control of plant pathogens (Kulik 1995). These biologically active compounds include antibiotics and toxins (De Caire et al. 1990; Bonjouklian et al. 1991; Carmichael 1992; FrankmÖlle et al. 1992a, b; Kiviranta et al. 2006). De Caire et al. (1990) reported that an extra-cellular product from $N$. muscorum is promising as a biological control of soybean seedlings damping off. $N$. muscorum has the ability to fix atmospheric nitrogen; this is making them good candidates for environments with low nitrogen content. Also, Anabaena flos-aquae is filamentous cyanobacterium that is known for their nitrogen-fixing abilities, and it forms symbiotic relationships with certain plants, such as the mosquito fern Spirulina platensis which is a filamentous, undifferentiated, non-toxigenic cyanobacterium that has been used as food since ancient times. It possesses other biological functions such as antiviral, antibacterial, antifungal, and antiparasite activities (Khan et al. 2005). 


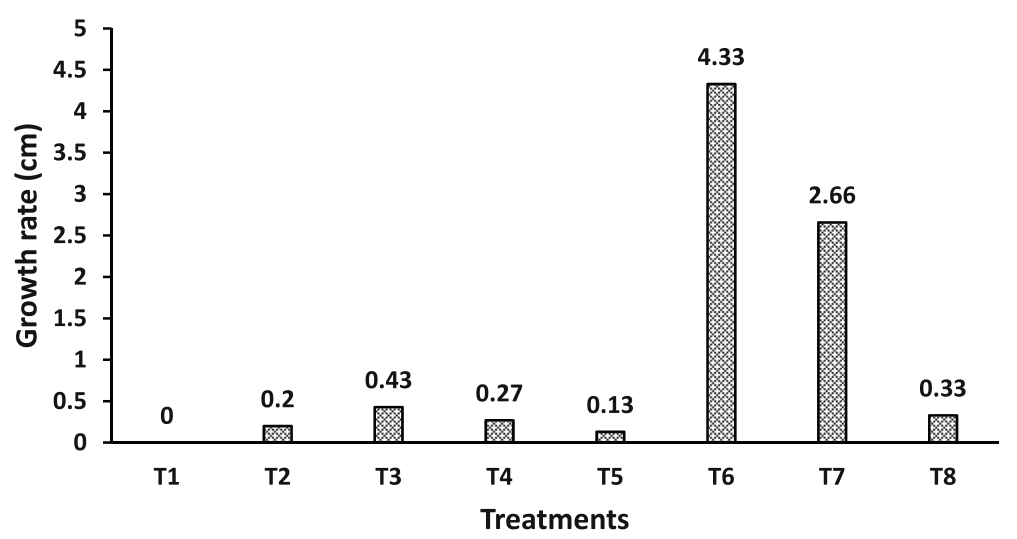

Fig. 4 The effect of different nano silver (ppm), algal extracts concentrations (\%) and Bacillus\% on growth rate of the Pectobacterium. T1 = Control, T2 = AgNps 50 ppm, T3 = AgNps 75 ppm, T4 = AgNps 100 ppm, T5 = Spirulina 50\%, T6 = Spirulina 75\%, T7 = Spirulina 100\% and T8 = Bacillus subtilis\%

The relationship between antagonistic microbes and plant pathogens may be complex. It may involve the production of antidisease chemicals, competition for space, and other necessities or triggering the host defensive mechanism and predation. Bacillus species have a unique ability to replicate rapidly, resistant to adverse environmental conditions, and they have broad spectrum of biocontrol ability. Volatile compounds produced by B. subtilis also play an important role in plant growth promotion and activation of plant defense mechanism by triggering the induced systemic resistance (ISR) in plants (Compant et al. 2005). The US Food and Drug Administration (US FDA) declared B. subtilis as GRAS (generally recognized as safe) microorganism for its use in food processing industries (Denner and Gillanders 1996).

B. subtilis is known to be biological control agent for the plant pathogen $P$. carotovora subsp. Carotovora. Many Bacillus species have proved to be effective against a broad range of plant pathogens (Bacon et al. 2001; Cook et al. 2002; Deng et al. 2011; Shafi et al. 2017 and Istiqomah and Toyibah (2013).

\section{Effect on endogenous enzymes}

Figure 5 shows that the induction of polyphenol oxidase (PPO) in the first application date after 81 days was significantly increased with all applied treatments compared to control (13 $\mathrm{mg} / \mathrm{min})$. B. subtilis $100 \%$ showed the most effect ( $84 \mathrm{mg} / \mathrm{min})$, followed by Spirulina $75 \%$, (57 mg/min), Spirulina 100\% (48 mg/min), and Ag Nps $75 \mathrm{ppm}$ and $44 \mathrm{mg} / \mathrm{min}$ though there were nonsignificant differences among them. Ag Nps $100 \mathrm{ppm}$ recorded $37 \mathrm{mg} / \mathrm{min}$ followed by Ag Nps 50 ppm $(22 \mathrm{mg} /$ min). S. platensis $50 \%$ produced the lowest significant effect in comparison to all treatments including control (2 $\mathrm{mg} / \mathrm{min}$ ). Concerning the second date of application, 102 days, the PPO activity expressed an opposite effect. Ag Nps 50 ppm showed the highest significant enzyme activity $(96 \mathrm{mg} / \mathrm{min})$. Meanwhile, the control treatment surpassed all treatments in a significant manner; the other treatments showed different significant effects. In the same manner, there were no significant differences among Ag Nps 75 ppm, Spirulina 50\%, Spirulina 100\%, and B. subtilis $100 \%$. The same trend may be observed
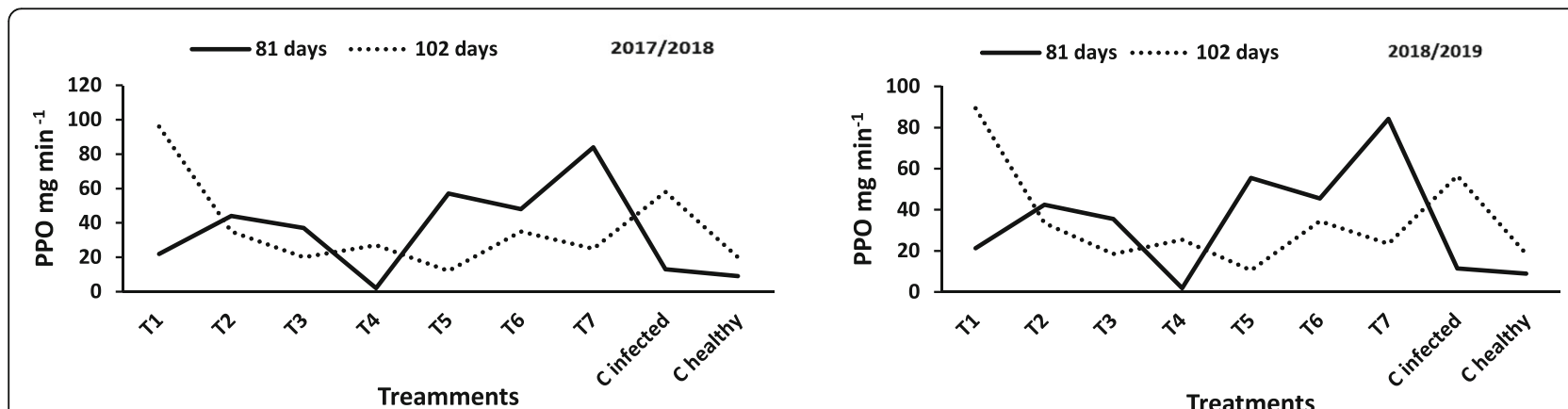

Fig. 5 Polyphenol Oxidase (PPO) activities for different treatments at two seasons. $\mathrm{T} 1=\mathrm{AgNps} 50$ ppm, T2 = AgNps 75 ppm, T3 = AgNps 100 ppm, T4 = Spirulina 50\%, T5 = Spirulina 75\%, T6 = Spirulina 100\% and T7 = Bacillus subtilis\% 

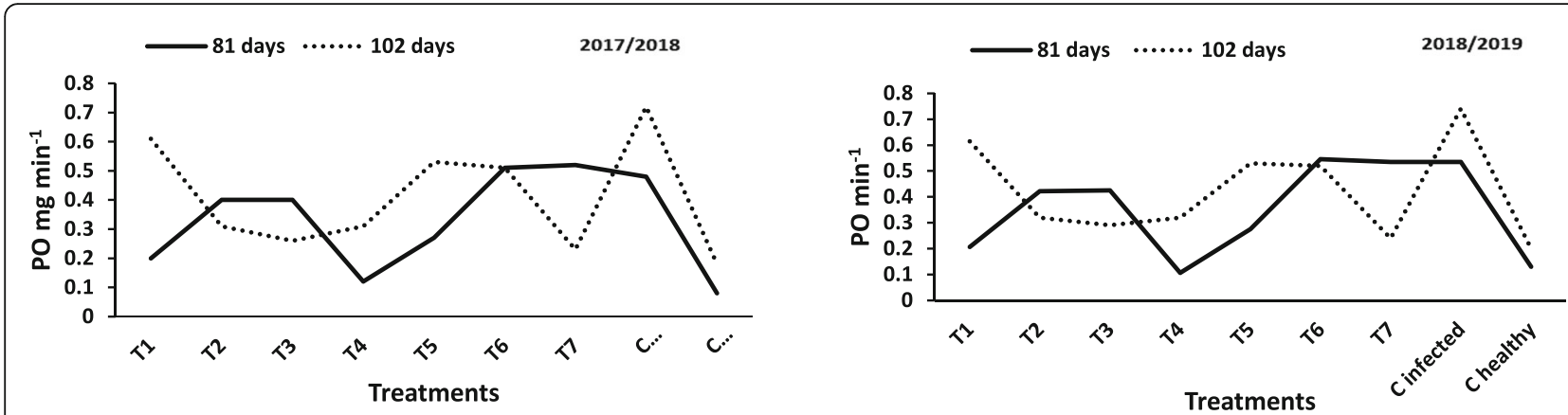

Fig. 6 Peroxidase $(\mathrm{PO})$ activities for different treatments at two seasons. $\mathrm{T} 1=\mathrm{AgNps} 50$ ppm, T2= AgNps 75 ppm, T3= AgNps 100 ppm, T4= Spirulina 50\%, T5 = Spirulina 75\%, T6 = Spirulina 100\% and T7 = Bacillus subtilis\%

at the second season. Bacillus $100 \%$ (84.17 $\mathrm{mg} / \mathrm{min})$, Spirulina $75 \%$ (55.0mg/min), Ag Nps 75 ppm (42.5 mg/ min), and Ag $100 \mathrm{Nps}$ ppm (35.5 mg/min) recorded a significant increment concerning PPO activity at 81 days after sowing compared to control $(11.5 \mathrm{mg} / \mathrm{min})$. That increment was followed by a significant decrement in the enzyme activity at 102 days after sowing. This finding was true for all experimented treatments except $\mathrm{Ag}$ Nps 50 ppm that highly showed increase in enzyme activity over the control and recorded $89.33 \mathrm{mg} / \mathrm{min}$ versus $56.5 \mathrm{mg} / \mathrm{min}$ for the control. Meanwhile, Spirulina 75\% recorded $10.5 \mathrm{mg} / \mathrm{min}$, Ag Nps $100 \mathrm{ppm} 18.5 \mathrm{mg} /$ min, and Bacillus $100 \% 23.5 \mathrm{mg} / \mathrm{min}$. The differences among them were significant.

On the contrary, the peroxidase (PO) activity during first application date showed different effects (Fig. 6). All treatments attained a significant decrement compared to control $(0.535 \mathrm{mg} / \mathrm{min})$ except treatment with Spirulina $100 \%$ increased significantly $(0.546 \mathrm{mg} /$ $\mathrm{min})$. The values of peroxidase activity may be arranged in an ascending order as follows: S. platensis 50\% (0.106 mg/min), Ag Nps 50 ppm (0.206 mg/ $\mathrm{min})$, Algae $75 \%$ (0.275 mg/min), Ag Nps $75 \mathrm{ppm}$ (0.422 mg/min), Ag Nps 100 ppm (0.425 mg/min), and
B. subtilis and control $(0.535 \mathrm{mg} / \mathrm{min})$. As for the second application date, the control recorded the highest significant value as $0.743 \mathrm{mg} / \mathrm{min}$, Ag Nps $50 \mathrm{ppm}$ was in the second rank in a significant pattern $(0.615 \mathrm{mg} / \mathrm{min})$, followed by S. platensis $75 \%$ and $100 \%$ ( 0.553 and 0.520 $\mathrm{mg} / \mathrm{min}$ ), respectively; although, no significant differences were found among them. The same observations were obtained with Ag Nps 75\%, Ag Nps 100 ppm, and Spirulina $50 \%$ as there were no statistical differences among them. Again, no significant differences recorded between $\mathrm{Ag}$ Nps 100 ppm and B. subtilis.

PPO is associated with the plant oxidation of plant phenolic compounds that may give the plant an additional resistance to pathogen invasion by providing increased contents of oxidized quinone and their derivatives that delay pathogen progress (Tyagi et al. 2000). Furthermore, Srivastava (1987) mentioned that at the early stages of the infection (on 6th day), resistant plants showed higher activities compared to their susceptible counterparts. Very low activity of these enzymes could be recorded in healthy plants. Findings of this study indicated the possible involvement of these oxidative enzymes in the resistance of this disease. More studies emphasized that the increase in activity of defense-

Table 3 Efficiency of the tested treatments against bacterial root rots in sugar-beet in pots and field at harvest

\begin{tabular}{|c|c|c|c|c|c|c|}
\hline \multirow[t]{2}{*}{ Treatments } & \multicolumn{2}{|l|}{ Pots experiment } & \multicolumn{2}{|c|}{ Field experiment first season } & \multicolumn{2}{|c|}{ Field experiment second season } \\
\hline & Disease incidence \% & Efficiency $\%$ & Disease incidence $\%$ & Efficiency $\%$ & Disease incidence \% & Efficiency\% \\
\hline Ag Nps 50 ppm & $33.33 c$ & 63.64 & 6.67 cde & 76.46 & $7.27 \mathrm{e}$ & 76.16 \\
\hline Ag Nps 75 ppm & $8.34 d$ & 90.90 & $2.50 \mathrm{e}$ & 91.18 & $3.30 \mathrm{~g}$ & 89.18 \\
\hline AgNps 100 ppm & $7.59 \mathrm{~d}$ & 91.72 & $1.67 \mathrm{e}$ & 94.11 & $2.27 \mathrm{~g}$ & 92.56 \\
\hline Sp $50 \%$ & $74.17 \mathrm{ab}$ & 19.10 & $15.00 \mathrm{~b}$ & 47.07 & $15.60 \mathrm{~b}$ & 48.85 \\
\hline Sp $75 \%$ & $58.34 \mathrm{~b}$ & 36.35 & $11.67 b c$ & 58.82 & $12.37 \mathrm{c}$ & 59.44 \\
\hline Sp $100 \%$ & $25.00 \mathrm{~cd}$ & 72.73 & $5.00 \mathrm{de}$ & 82.36 & $5.60 \mathrm{f}$ & 81.64 \\
\hline Bs $100 \%$ & $83.34 \mathrm{a}$ & 9.10 & $10.00 \mathrm{bcd}$ & 64.71 & $10.60 d$ & 65.25 \\
\hline Control & $91.67 \mathrm{a}$ & - & $28.34 \mathrm{a}$ & - & $30.50 \mathrm{a}$ & - \\
\hline LSD & \multicolumn{2}{|c|}{$1 \%=32.790$ and $5 \%=24.097$} & \multicolumn{2}{|c|}{$1 \%=7.017$ and $5 \%=5.153$} & \multicolumn{2}{|c|}{$1 \%=1.882$ and $5 \%=1.275$} \\
\hline
\end{tabular}

Sp Spirulina platensis, Bs Bacillus subtilis

In a column means followed by a common letter are not significantly different at $1 \%$ level by DMRT 
related enzymes, as peroxidase (PO) or polyphenol oxidase (PPO), has been elicited by bio-control agent strains in different plants (Govindappa et al. 2010). PO and $\mathrm{PPO}$ are thought to protect cell walls (lignification and suberization) at the start of infection and further limit spread of pathogens (Passardi et al. 2004).

In the early stages of the infection (on 6th day), resistant plants showed higher activities compared to their susceptible counterparts. Very low activity of these enzymes could be recorded in healthy plants. Findings of this study indicate the possible involvement of these oxidative enzymes in the resistance of this disease (Srivastava 1987).

\section{Effect on the sugar quality}

The sugar quality is an important parameter for sugar beet industry. So, it is essential to determine the effect of the agricultural treatments on sugar quality at harvest. In the present study, sucrose $\%$ at the first season (Table 4) showed that spraying Ag Nps 100 ppm recorded the highest significant increase value (20.5\%) followed by Spirulina platensis 75\% (19) and Ag Nps 75 ppm (18.9); however, the differences among them were not statistically significant. Using Ag Nps 50 ppm and Spirulina 100\% gave the same non-significant values (18.2 and 18\%), respectively. Bacillus 100\%, S. platensis 50\%, and control gave the lowest sucrose \%. The recorded increase values were 17.5, 17, and $16.3 \%$, respectively. In the second season, Ag Nps 100 ppm gave $20.83 \%$ which surpassed all treatments statistically followed by Spirulina (75\%) with $20.13 \%$. The differences among the other treatments were not statistically significant. Concerning the impurities as $\mathrm{Na}, \mathrm{K}$, and $\alpha$ amino nitrogen significantly varied among the different treatments. For instance, $\mathrm{Na} \%$ at both seasons was significantly high with control compared to other treatments. It recorded 2.5 and $2.37 \%$, respectively. On the other hand, K \% result showed that Spirulina 100\% and Bacillus100\% recorded the highest significant values, i.e., 6 and 5.9\%, in the first season and 6.03 and $5.63 \%$ in the second one, respectively, compared to other treatments including control. As for the $\alpha$-amino nitrogen, control treatment surpassed all the studied treatments in a significant manner recording 6.8 and $7 \%$ in both seasons, respectively. Concerning the purity (QZ \%), control attained the lowest values in both seasons; however, the differences among the other treatments were close and showed certain significant values. For illustration, in the first season, S. platensis $75 \%$ and all Nps treatments recorded values ranging from 85 to $83 \%$.

The same effect was almost observed in the second season. The healthy sugar beet mean values for sucrose $17.16 \%, \mathrm{Na} 1.6 \%, \mathrm{~K} 4.78 \%, \alpha$-amino nitrogen $1.93 \%$, and purity (QZ) $82 \%$ according to AbdelFattah and El-Geddawy (2015). In this investigation, all studied treatments recorded the highest values concerning sucrose and purity percentages up to $20.8 \%$ and $85 \%$, respectively. This may be referred to the effect of the treatments on the general health of the beets. Also, the different treatments may have effect on the storage parenchyma tissues where the sucrose is stored, but this point need further study in the future.

Previous studies were in agreement with our findings, explaining a positive and inversely proportional relationship between activity of the enzymes and the disease incidence. For example, the activity of both enzymes was high after the first application and decreased after the second one when using nanosilver preparations at 100 and $75 \mathrm{ppm}$. The disease incidences were 1.67 and $2.50 \%$ with efficiency \% recorded 94.11 and $91.18 \%$, respectively. The increment in activity at the beginning was to fight the pathogen followed by decrement after the plant was being strong enough to overcome the invasion, and this was

Table 4 Chemical composition of the roots after different treatment

\begin{tabular}{|c|c|c|c|c|c|c|c|c|c|c|}
\hline \multirow[t]{2}{*}{ Treatments } & \multicolumn{5}{|l|}{ Season $2017 / 2018$} & \multicolumn{5}{|c|}{ Season $2018 / 2019$} \\
\hline & Sucrose $\% 5 \% \% \%$ & $\mathrm{Na} \%$ & $\mathbf{K} \%$ & $\begin{array}{l}\text { a-amino } \\
\text { nitrogen }\end{array}$ & Q.Z\% & Sucrose\% & $\mathrm{Na} \%$ & $\mathrm{~K} \%$ & $\begin{array}{l}\text { a-amino } \\
\text { nitrogen }\end{array}$ & Q.Z\% \\
\hline Ag Nps 50 ppm & $18.2 \mathrm{C}$ & $1.2 \mathrm{cde}$ & $4.7 a b c$ & $3.0 \mathrm{e}$ & $82 \mathrm{bcd}$ & $19.03 \mathrm{C}$ & $1.73 \mathrm{C}$ & $5.00 \mathrm{C}$ & $3.20 \mathrm{f}$ & $82.87 \mathrm{abc}$ \\
\hline Ag Nps 75 ppm & $18.9 \mathrm{~b}$ & $1.5 \mathrm{C}$ & $4.2 \mathrm{bc}$ & $4.5 c$ & 83.9ab & 19.02 C & $1.83 \mathrm{bc}$ & $4.47 d$ & $4.50 \mathrm{~d}$ & $84.20 \mathrm{abc}$ \\
\hline Ag Nps 100 ppm & $20.5 \mathrm{a}$ & $1.3 \mathrm{~cd}$ & $5.7 \mathrm{ab}$ & $4.7 c$ & $84.5 a b$ & $20.83 a$ & $1.70 \mathrm{C}$ & $5.53 \mathrm{~b}$ & $4.43 \mathrm{de}$ & $85.10 \mathrm{a}$ \\
\hline Sp $50 \%$ & $17 \mathrm{e}$ & $0.9 e$ & $4.2 \mathrm{bc}$ & $4.9 c$ & $83 a b c$ & $18.09 \mathrm{~d}$ & $1.07 \mathrm{~d}$ & 4.30 de & $5.00 \mathrm{C}$ & $83.93 \mathrm{abc}$ \\
\hline Sp 75\% & $19 b$ & $1 \mathrm{de}$ & $4 c$ & $5.6 b$ & $85 a$ & $20.13 b$ & $1.23 \mathrm{~d}$ & 4.03 e & $5.77 b$ & $85.00 \mathrm{ab}$ \\
\hline Sp $100 \%$ & $18 c$ & $1.9 \mathrm{~b}$ & $6 a$ & $3.0 \mathrm{e}$ & $80 d$ & 18.96 C & $2.03 \mathrm{~b}$ & $6.03 a$ & $3.40 \mathrm{f}$ & $81.77 b c$ \\
\hline Bs & $17.5 \mathrm{~d}$ & $1.1 \mathrm{de}$ & $5.9 a$ & $3.9 d$ & $80.5 \mathrm{~cd}$ & $18.73 \mathrm{C}$ & $1.63 \mathrm{C}$ & $5.63 b$ & 4.03 e & 81.47 C \\
\hline Control & $16.3 \mathrm{f}$ & $2.5 \mathrm{a}$ & $4.5 \mathrm{abc}$ & $6.8 a$ & $76 e$ & $17.07 \mathrm{e}$ & $2.37 \mathrm{a}$ & 4.30 de & $7.00 \mathrm{a}$ & $73.67 \mathrm{~d}$ \\
\hline LSD 5\% & 0.35 & 0.35 & 1.5 & 0.52 & 2.5 & 0.445 & 0.225 & 0.346 & 0.407 & 3.290 \\
\hline
\end{tabular}

Sp Spirulina platensis, Bs Bacillus subtilis

In a column means followed by a common letter are not significantly different at $1 \%$ level by DMRT 
clearly noticed at the harvest stage where the least disease incidence was recorded. On the other hand, Spirulina 50\% and Ag Nps 50 ppm showed adverse effect where the activity of enzymes increased after the second application which led us to assume that the plant was suffering from dealing with the pathogen invasion. This assumption was confirmed by the disease incidence at harvest which recorded 28.34, 15, and $6.67 \%$, respectively.

\section{Conclusion}

This investigation results in the relay on bio-control methods and modern agriculture as nano-agrochemicals. The disease incidence \% of bacterial soft rot was significantly decreased with all treatments. This was reflected on the final product which is sucrose and purity percentages.

\section{Abbreviations}

Ag NPs: Silver nanoparticles; S.P.: Spirulina platensis; B.S.: Bacillus subtilis; PO: Peroxidase; PPO: Poly phenol oxidase; ppm: Part per million

\section{Acknowledgements}

The authors are grateful to the colleagues in Plant Pathology Research Institute, Egypt, for the facilities provided for conducting this study.

\section{Authors' contributions}

This work has been carried out with the collaboration among all the authors. Author NG has designed the study, performed the statistical analysis, and wrote the manuscript. Authors OA, MA, and ED managed the literature searches and arranged the bibliography of the paper. All authors have read and approved the final manuscript.

\section{Funding}

None.

\section{Availability of data and materials}

Data and materials in this study can be used as a reference by other researchers.

\section{Ethics approval and consent to participate}

Not applicable.

\section{Consent for publication}

Not applicable.

\section{Competing interests}

The authors declare that they have no competing interests.

\section{Author details}

${ }^{1}$ Maize and Sugar Crops Diseases Department, Plant Pathology Research Institute, Agricultural Research Center, Giza 12112, Egypt. ${ }^{2}$ Bacterial Plant Diseases Department, Plant Pathology Research Institute, Agricultural Research Center, Giza 12112, Egypt. ${ }^{3}$ Sugar Crops Research Institute (SCRI), Agricultural Research Center, Giza 12112, Egypt.

Received: 26 July 2020 Accepted: 6 December 2020

Published online: 02 January 2021

\section{References}

Abdalla ME, Seadh SE, Hamza S (2019) Inhibitory effect and morphological changes by organic acids to bacterial strains causing sugar beet soft root rot In Vitro. J Plant Prot and Path Mansoura Univ. 10(3):187-193

Abdel-Aziz MS, Shaheen MS, El-Nekeety AA, Abdel-Wahhab MA (2014) Antioxidant and antibacterial activity of silver nanoparticles biosynthesized using Chenopodium murale leaf extract. J Saudi Chem Soc 18(4):356-363
Abdel-Fattah Al, El-Geddawy DIH (2015) Nitrogen fertilization and its effect on spread of Cercospora Beticola as well as the yield and quality of six sugar beet varieties under natural condition. J Boil Chem Environ Sci 10(1):103-126

Abdel-Kader MM (1997) Field application of Trichoderma harzianum as biocide for control bean root-rot disease. Egypt J Phytopathol 25:19-25

Al-Samarrai AM (2012) Nanoparticles as alternative to pesticides in management plant diseases a review. Int J Sci Res Publ 2(4):1-4

Álvarez SP, López NEL, Lozano JM, Negrete EAR, Cervantes MES (2016) Plant fungal disease management using nano-biotechnology as a tool. In: Prasad R (ed) Advances and Applications through Fungal Nano biotechnology, Fungal Biology, pp 169-192

Anonymous (1957) Manual of Microbiological Methods. McGraw Hill Book Company Inc, New York, p 127

Bacon CW, Yates IE, Hinton DM, Meredith F (2001) Biological control of Fusarium moniliforme in maize. Environ Health Perspect 109(Suppl. 2):325-332

Bakht J, Islam A, Shafi M (2011) Antimicrobial potentials of eclipta alba by well diffusion method. Pak J Bot 43:169-174 Special Issue, December, 2011 (Medicinal Plants: Conservation \& Sustainable use)

Bastas K K, Kaya R (2019) Determination of root rots bacterial pathogens on sugar beets in central Anatolia and susceptibilities of commonly cultivated sugar beet cultivars to pectobacteria. 6th International Conference on Sustainable Agriculture and Environment October 3-5, 2019, City of Konya Turkey.

Bhattacharyya A, Duraisamy P, Govindarajan M, Buhroo AA, Prasad R (2016) Nano-bio-fungicides: emerging trend in insect pest control. In: Prasad R (ed) Advances and Applications through Fungal Nano-biotechnology, Fungal Biol, pp 307-319

Bonjouklian R, Smitka TA, Doolin LE, Molloy RM, Debono M, Shaffer SA, Moore RE, Stewart JB, Patterson GM, Tjipanazoles L (1991) New antifungal agents from the blue-green alga Tolypothrix tjipanasensis. Tetrahedron 47:7739-7750

Bull CT, De Boer SH, Denny TP, Firrao G, Saux MFL, Saddler GS, Scortichini M, Stead DE, Takikawa Y (2010) Comprehensive list of names of plant pathogenic bacteria, 1980-2007. J Plant Pathol 92(3):551-592

Campos EV, De Oliveira RJL, Fraceto LF, Singh B (2015) Polysaccharides as safer release systems for agrochemicals. Agron Sustain Dev 35:47-66

Carmichael WW (1992) Cyanobacteria secondary metabolites- the cyanotoxines. J Appl Bact 72:445-459

Cavaglieri L, Orlando J, Etcheverry M (2005) In vitro influence of bacterial mixtures on Fusarium verticillioides growth and fumonisin B1 production: effect of seeds treatment on maize root colonization. Lett Appl Microbiol 41(5):390396

Compant S, Duffy B, Nowak J, Clément C, Barka EA (2005) Use of plant growth promoting bacteria for biocontrol of plant diseases: principles, mechanisms of action, and future prospects. Appl Environ Microbiol 71(9):4951-4959

Cook RJ, Weller DM, El-Banna AY, Vakoch D, Zhang H (2002) Yield responses of direct-seeded wheat to rhizobacteria and fungicide seed treatments. Plant Dis 86(7):780-784

Darroudi M, Ahmad MB, Zak AK, Zamiri R, Hakimi M (2011) Fabrication and characterization of gelatin stabilized silver nanoparticles under UV-light. Int J Mol Sci 12:6346-6356

De Caire GZ, De Cano MS, De Mule MCZ, De Halperin DR (1990) Antimycotic products from the cyanobacterium Nostoc muscorum against Rhizoctonia solani. Phyton Buenos Aires 51:1-4

Deng Y, Zhu Y, Wang P, Zhu LZ, Eng J, Li R, Ruan L, Peng D, Sun M (2011) Complete Genome Sequence of Bacillus subtilis BSn5, an Endophytic Bacterium of Amorphophallus konjac with Antimicrobial Activity for the Plant Pathogen Erwinia carotovora subsp. Carotovora. J Bacteriol 193(8):2070-2071

Denner W, Gillanders T (1996) The legislative aspects of the use of industrial enzymes in the manufacture of food and food ingredients. In: Godfrey T, Reichelt J (eds) Industrial enzymology. Stockton Press, New York, pp 397-412

Difco Manual 9th ed. (1953) Difco Laboratories. Inc., Detroit. Mich. C.f. Johnson, L. F. and Curl, E. A. (1972). Methods for research on the ecology of soil-born plant pathogens. Burgess publishing company. USA.

Dubey A, Mailapalli DR (2016) Nanofertilisers, nanopesticides, nanosensors of pest and nanotoxicity in agriculture. In: Lichtfouse E (ed) Sustainable Agriculture Reviews, Sust Agric Rev, vol 19. Springer International Publishing, Switzerland, pp 307-330. https://doi.org/10.1007/978-3-319-26777-7_7

EL-Bakery AM (2010) Biological control of Cephalosporium maydis the causal organism of late wilt disease on maize. MSc Thesis Fac Sci Zagazig Univ Egypt, p 108 
El-Mougy NS, Abdel-Kader MM (2013) effect of commercial cyanobacteria products on the growth and antagonistic ability of some bio agents under laboratory conditions. J Patho Article ID 838329, 11; https://doi.org/10.1155/ 2013/838329; PMID: 24307948

Esteban-Tejeda L, Malpartida F, Esteban-Cubillo A, Pecharromán C, Moya JS (2009) Antibacterial and antifungal activity of a soda-lime glass containing copper nanoparticles. Nanotechnol 20(50):505-701

FrankmÖlle WP, Knubal G, Moorc RI, Patterson GMI (1992b) Antifungal cyclic peptides from the terrestrial blue-green alga Anabaena laxa. Structures of laxaphycins A B C D and E. J Anti 45:1458-1466

FrankmÖlle WP, Larsen LK, Caplan FR, Patterson GMI, Knuabal G, Levine IA, Moore RE (1992a) Antifungal cyclic peptides from the terrestrial blue-green algae Anabaena laxa. Isolations and biological properties. J Anti 45:1451-1457

Garrity GM, Bell JA, Lilburn TG (2004) Taxonomic outline of The prokaryotes bergey'smanual ${ }^{\oplus}$ Of systematic bacteriology, 2nd edn

Gomez KA, Gomez AA (1984) Statistical procedures for agricultural research. John Wiley \& Sons.

Govindappa M, Lokesh S, Ravishankar VR, Rudranaik V, Raju SC (2010) Induction of systemic resistance and management of safflower Macrophomina phaseolina root rot disease by biocontrol agents. Arch Phytopathol Plant Prot 43:26-40

Harveson RM, Hanson LE, Hein GL (2009) Compendium of beet diseases and pests, 2nd edn. APS Press, American Phytopathological Society, St. Paul

Harvey CW, Dutton J V (1993) Root quality and processing. In The sugar beet crop (pp. 571-617). Springer, Dordrecht

Hewedy MA, Rahhal MMH, Ismail IA (2000) Pathological studies on soybean damping-off disease. Egypt J Appl Sci 15:88-102

Istiqomah JC, Toyibah ES (2013) The $1^{\text {st }}$ Annual International Conferrence in Taiwan Biological Control of Potato Soft Rot Disease (Erw inia carotovora) USING Bacillus subtilis AND Pseudomonas fluorescens, AISC Taiwan. ISSN: 2337$442 X$

Jo YK, Kim BH, Jung G (2009) Antifungal activity of silver ions and nano-particles on phytopathogenic fungi. Plant Dis 93(10):1037-1043

Khan Z, Purk SD, Shin SY, Boe SG, Yeon IK, Seo JJ (2005) Management of Meloidogyne incognita on tomato by root-dip treatment in culture filtrate of the blue-green algae, Microcoleus vaginatus. Bio Re Technol 96:1338-1341

Kiviranta J, Abdel-Hameed A, Sivonen K, Niemelä SI, Carlberg G (2006) Toxicity of cyanobacteria to mosquito larvae screening of active compounds. Envrion. Toxicol. Water Qual 8:63-71

Kulik MM (1995) The potential for using cyanobacteria (blue-green algae) and algae in the biological control of plant pathogenic bacteria and fungi. Euro J plant pathol 101(6):585-599.

Lamsal KK, Jung SW, Kim JH, Kim KS, Lee YS (2011) Inhibition effects of silver nanoparticles against powdery mildews on cucumber and pumpkin. Microbiol 39(1):26-32

Lobarzewski J (1990) The characteristics and functions of the peroxidases fromTrametes versicolor in lignin biotransformation. J Biotechnol 13:111-117

Mariey SA, Farid MA, Khatab IA (2016) Physiological and molecular characterization of some Egyptian barley (hordeum vulgare l.) cultivars for salt tolerance. Egypt $J$ Genet Cytol 45:367-382 July, 2016 Web Site (www.esg.net.eg)

Metzger MS (2018) Characterization of pectobacterium carotovorum subsp. Brasiliense as a causal agent of sugar beet soft rot. Ph.D. Thesis, Major Department, Plant Pathology, North Dakota State University of Agric Appl Sci, p 45

Ocsoy I, Paret ML, Ocsoy MA, Kunwar S, Chen T, You M, Tan W (2013) Nanotechnology in plant disease management: DNA-directed silver nanoparticles on graphene oxide as an antibacterial against Xanthomonas perforans. ACS Nano 7(10):8972-8980

Pandey JP, Neeraj P, Tiwari A (2010) Standardization of pH and light intensity for the biomass production of Spirulina platensis. J Algal Bio UtIn 1(2):93-102

Pandey S, Giri K, Kumar R, Mishra G, Raja RR (2016) Nanopesticides: Opportunities in Crop Protection and Associated Environmental Risks. Proc Natl Acad Sci India Sect B Biol Sci. https://doi.org/10.1007/s40011-016-0791-2

Papavizas GC, Lumsden RD (1980) Biological control of soil- borne fungal propagules. An Rev Phytopathol 18:389-413

Park HJ, Kim SH, Kim HJ, Choi SH (2006) A new composition of nanosized silicasilver for control of various plant diseases. J Plant Pathol 22(3):295-302

Passardi F, Penel C, Dunand C (2004) Performing the paradoxal: how plant peroxidases modify the cell wall. Trends Plant Sci 9:534-540
Pokhrel LR, Brajesh D (2013) Evaluation of developmental responses of two crop plants exposed to silver and zinc oxide nanoparticles. Sci Total Environ 452: 321-32

Priebe MJ, Widmer Löwa NS, Abram SL, Mottas I, Woischnig AK, Brunetto PS, Khanna N, Bourquin C, Fromm KM (2017) Antimicrobial silver-filled silica nanorattles with low immunotoxicity in dendritic cells. Nanomed: Nanotechnol, Biol Med 13(1):11-22

Pulimi M, Subramanian S (2016) Nanomaterials for Soil Fertilisation and Contaminant Removal. In: Ranjan S et al (eds) Nanoscience in Food and Agriculture 1, Sustainable Agriculture Reviews, vol 20. Springer, Cham: Springer International Publishing Switzerland, pp 229-246. https://doi.org/10. 1007/978-3-319-39303-2_8

Rabie GH, Zein El-Abedeen A, Bakry Amal A (2013) Biological synthesis of silver nanoparticles using filamentous fungi. Nano Sci and NanoTechnol 7(5):163-171

Ram Prasad PVK, Suranjit PK (2014) Nanotechnology in sustainable agriculture: present concerns and future aspects. Afr J Biotechnol 13(6):706-713

Read DS, Matzke M, Gweon HS, Newbold LK, Heggelund L, Ortiz MD, Lahive E, Spurgeon D, Svendsen C (2016) Soil pH effects on the interactions between dissolved zinc, non-nano- and nano-ZnO with soil bacterial communities. Environ Sci Pollut Res 23:4120-4128

Samarajeewa AD, Velicogna JR, Princz Jl, Subasinghe RM, Scroggins RP, Beaudette LA (2017) Effect of silver nano-particles on soil microbial growth, activity and community diversity in a sandy loam soil. Env Poll 220(Part A):504-513

Sathishkumar M, SnehaK WSW, Cho CW, Kim S, Yun YS (2009) Cinnamon zeylanicum bark extract and powder mediated green synthesis of nanocrystalline silver particles and its bactericidal activity. Colloids Surf B: Biointerfaces. 73(2):332-338

Schaad NW (2001) Initial identification of common genera. In: Schaad NW, Jones JB, Chun W (eds) Laboratory guide for identification of plant pathology bacteria, 3rd edn. APS Press, St Paul, pp 1-9

Sekhon BS (2014) Nanotechnology in agri-food production: an overview. Nanotechnol Sci Appl 7:31-53

Shafi J, Tian H, Ji M (2017) Bacillus species as versatile weapons for plant pathogens: a review. Biotechnol Biotechnol Equip 31(3):446-459

Simonin M, Richaume A (2015) Impact of engineered nanoparticles on the activity, abundance, and diversity of soil microbial communities: a review. Environ Sci Pollut Res 22:13710-13723. https://doi.org/10.1007/s11356-0154171-x

Sotokawa N, Takikawa Y (2004) Occurrence of bacterial rot of onion bulbs caused by Burkholderia cepacia in Japan. J Gen Plant Pathol 70:348-352

Srivastava SK (1987) Peroxidase and poly-phenol oxidase in Brassica juncea Plants Infected with Macrophomina phaseolina (Tassai) Goid. and their Implication in Disease Resistance. J phytopathol 120(3):249-254

Thomson JB, Schroth MN (1977) Occurrence of soft-rot Erwinia spp. in soil and plant material. Phytopathol 67:1382-1387

Thomson SV, Schroth MN (1972) Vascular necrosis and rot of sugar beets. Calif. Plant Pathol 12:1-2

Tripathi DK, Singh S, Singh S, Pandey R, Singh VP, Sharma NC, Prasad SM, Dubey NK, Chauhan DK (2017) An overview on manufactured nanoparticles in plants: Uptake, translocation, accumulation and phytotoxicity. Plant Physiol Biochem 110:2-12

Tyagi M, Arvind MK, Sinha B (2000) The role of peroxidase and polyphenol oxidase isozymes in wheat resistance to Alternaria triticina. Biol Plant 43(4): 559-562

Vidaver-Anne K, Mathys-Mary L, Thomas E, Schuster ML (1972) Bacteriocins of the phytopathogens Pseudomonas syringe, P glycinea and P. phaseolicola. Canad J Microbiol 18(6):705-713

Wu J, Xie Y, Fang Z, Cheng W, Tsang PE (2016) Effects of Ni/Fe bimetallic nanoparticles on phytotoxicity and translocation of polybrominated diphenyl ethers in contaminated soil. Chemosphere 162:235-242

Zarrouk C (1966) Contribution a l'etude d'une cyanobacterie: influence de divers facteurs physiques et chimiques sur la croissance et la photosynthese de Spirulina maxima (Setchell et Gardner) Geitler. PhD thesis, University of Paris, France.

Zhang W, Dan Y, Shi H, Ma X (2017) Elucidating the mechanisms for plant uptake and in-planta speciation of cerium in radish (Raphanus sativus L.) treated with cerium oxide nanoparticles. J Environ Chem Eng 5(1):572-577

\section{Publisher's Note}

Springer Nature remains neutral with regard to jurisdictional claims in published maps and institutional affiliations. 